\title{
PERFLUORODECALIN AND BONE REGENERATION
}

\author{
F. Tamimi ${ }^{1, *}$, P. Comeau ${ }^{1}$, D. Le Nihouannen ${ }^{2}$, Y.L. Zhang ${ }^{1}$, D.C. Bassett ${ }^{1}$, S. Khalili ${ }^{1}$, U. Gbureck ${ }^{3}$, S.D. Tran ${ }^{1}$, \\ S. Komarova ${ }^{1}$, and J.E. Barralet ${ }^{1}$
}

\author{
${ }^{1}$ Faculty of Dentistry, McGill University, Montreal, Quebec, Canada \\ ${ }^{2}$ University of Bordeaux, Bordeaux, France \\ ${ }^{3}$ University of Würzburg, Würzburg, Germany
}

\begin{abstract}
Perfluorodecalin (PFD) is a chemically and biologically inert biomaterial and, as many perfluorocarbons, is also hydrophobic, radiopaque and has a high solute capacity for gases such as oxygen. In this article we have demonstrated, both in vitro and in vivo, that PFD may significantly enhance bone regeneration. Firstly, the potential benefit of PFD was demonstrated by prolonging the survival of bone marrow cells cultured in anaerobic conditions. These findings translated in vivo, where PFD incorporated into bone-marrow-loaded 3D-printed scaffolds substantially improved their capacity to regenerate bone. Secondly, in addition to biological applications, we have also shown that PFD improves the radiopacity of bone regeneration biomaterials, a key feature required for the visualisation of biomaterials during and after surgical implantation. Finally, we have shown how the extreme hydrophobicity of PFD enables the fabrication of highly cohesive self-setting injectable biomaterials for bone regeneration. In conclusion, perfluorocarbons would appear to be highly beneficial additives to a number of regenerative biomaterials, especially those for bone regeneration.
\end{abstract}

Keywords: Perfluorocarbons; bone regeneration; bone marrow; bone; biomaterials; radiopacity.

*Address for correspondence:

Faleh Tamimi

Faculty of Dentistry, McGill University

3640 University Street,

Montreal, Quebec H3A 2B2, Canada

Telephone Number: +1 514-398-7203 ext 09654

FAX Number: +1 514-398-8900

E-mail: faleh.tamimimarino@mcgill.ca
Introduction

Bone repair and regeneration is highly dependent on the progeny of mesenchymal stem cells (MSCs) and their ability to affect healing at an injured site. Upon bone injury, bone marrow (BM) provides large numbers of MSCs that replicate and differentiate to lineages of mesenchymal tissues, including bone, and marrow stroma (Caplan, 1991; Pittenger et al., 1999; Jiang et al., 2002). Despite these properties, MSCs alone have proven to be unable to promote bone repair, and they require the support of a scaffolding biomaterial. Synthetic scaffolds allow cell migration, growth and differentiation into the site; however, they lack the biological activity of MSCs. Therefore, current research on bone healing focuses on seeding scaffolds with MSCs that will later help in the formation bone tissue (Bueno and Glowacki, 2009). Autologous bone marrow cells seeded into synthetic scaffolds have shown great potential in bone tissue engineering, and have been considered to be a potential candidate to replace autologous bone grafts as the material of choice for bone repair (Ohgushi et al., 1989; Goshima et al., 1991; Cheema et al., 2008; Meijer et al., 2008; Bueno and Glowacki, 2009; Kruyt et al., 2009).

However, a major obstacle to this approach has been the survival of implanted cells (Meijer et al., 2008; Kruyt et al., 2009). In the short term, cellular survival depends on the availability of oxygen and nutrients, and also on the removal of metabolites. This process is facilitated by the vasculature, yet at implantation and during initial healing the blood supply in tissue-engineering scaffolds is compromised, which in turn causes local hypoxia and reduces cell vitality within implanted matrices (Cheema et al., 2008). One approach to alleviate this problem would be to provide a local oxygen source that would maintain cell viability until blood supply is restored. This concept has been evaluated for the regeneration of soft tissues by releasing oxygen from perfluorocarbons (PFCs) (Riess et al., 1988; Soman and Banerjee, 2003; Tan et al., 2009). PFCs are organic molecules where all hydrogen groups have been substituted with fluorine. These molecules are very stable, biologically inert and are easily eliminated by the body (Putyatina et al., 1994). PFCs have been found to dissolve high concentrations of oxygen that is released when the partial pressure of oxygen is reduced in the surrounding environment (Tan et al., 2009). For these reasons PFCs have been used in the biomedical field for many years as artificial vitreous replacements or synthetic oxygen carriers (artificial blood) (Riess et al., 1988; Riess and Krafft, 1998; Soman and Banerjee, 2003; Tan et al., 2009). Perfluorodecalin $\left(\mathrm{C}_{10} \mathrm{~F}_{18}\right.$; PFD) is a particularly interesting PFC due to its high oxygen storage capacity, 
and low vapour pressure, which renders it useful for oxygen delivery in the body (Riess et al., 1988; Riess and Krafft, 1998; Roser et al., 1999; Soman and Banerjee, 2003; Tan et $a l ., 2009)$. Its density $\left(1.92 \mathrm{~g} / \mathrm{cm}^{3}\right)$ and viscosity $(2.61 \mathrm{cS})$ are higher than water; therefore, it is a very useful liquid for the formulation of stable suspensions for injectable materials (Song-Ling and Maturo, 1975; Roser et al., 1999; Jeng et al., 2003). Moreover, PFD is radiopaque, and therefore has potential to act as a contrast agent for clinical radiologically guided procedures.

Injectability is a pertinent topic in spine and maxillofacial surgery since it allows treatment via minimally invasive techniques. Bone cements are used as injectable biomaterials in different clinical applications, and set in vivo into hard functional materials (Gbureck et al., 2007a; Tamimi et al., 2009b). A cement paste consists of a suspension of solid particles in a liquid, and injectability of these materials is highly dependent on the stability of this suspension. Stable suspensions are best obtained when the liquid phase and the solid phase have a similar density. Improvements to the injectability of calcium phosphate cements (CPCs) have been achieved by increasing the amount of water in the cement, reducing the solid particle size and using additives such as hyaluronic acid and citrate ions (Barralet et al., 2004; Bohner et al., 2006). Despite effective setting rate controllers being developed (Barralet et al., 2004), setting times still vary with ambient temperature and premixed set-on-injection cements are desirable to aid clinical application. Selfsetting premixed cements, based on glycerol, and other hydrophilic non-aqueous and non-toxic liquids, have been reported (Carey et al., 2005; Xu et al., 2007). However, the carrier liquid is inert and offers no additional biological or clinical functionality to the material.

We hypothesised that PFD would considerably improve the physical and functional properties of calcium phosphate bioceramics for bone regeneration in two ways: firstly, by increasing radiopacity and injectability, and secondly, by improving their biological performance (i.e., oxygen delivery). Accordingly, in this study we investigated the effect of PFD on radiopacity, cohesion, and injectability of brushite cement, and the resulting cement was tested for in vitro and in vivo compatibility with living cells and tissues. Additionally, the effect of PFD gas storage capacity on bone marrow cells was investigated in vitro in cell cultures. Finally, the bone regeneration capacity of 3D printed cement matrices loaded with PFD and BM cell was assessed in vivo in long-bone defects in rabbits.

\section{Materials and Methods}

The aim of this study was to determine the potential benefits of using PFD as a biomaterial for bone regeneration. The effect of PFD on the physical-chemical properties of injectable brushite cements was determined and we also investigated the effect of PFD on bone cells in vivo and in vitro, alone and in combination with brushite cement.

\section{Preparation of PFD}

PFD was purchased from Sigma-Aldrich (St. Louis, MO, USA). Oxygen-loaded PFD ( $\mathrm{O}_{2}$-PFD) was prepared by, bubbling the PFD with compressed air at a pressure of $10 \mathrm{mbar}$ for $15 \mathrm{~min}$ at room temperature (conditions shown to be optimal for saturating PFD with dissolved oxygen (Jewitt et al., 1999; Pilarek and Szewczyk, 2008)). The compressed air line was filtered by an indicating moisture trap and a hydrocarbon trap (Restek, Bellefonte, PA, USA). De-oxygenated PFC ( $\mathrm{N}_{2}$-PFD) was prepared by bubbling pure $\mathrm{N}_{2}$ gas at a pressure of 10 mbar through PFD for $15 \mathrm{~min}$ at room temperature (Jewitt et al., 1999; Pilarek and Szewczyk, 2008). PFD liquids were then sterilised by micro-filtration $(0.22 \mu \mathrm{m}$ filter, Millipore, Billerica, MA, USA).

\section{Calcium phosphate cement combined with PFD (PFD-CPC)}

Two types of cements were prepared in order to test the combination of PFD with calcium phosphate. A non-setting cement was prepared to assess injectability and radiopacity of the mixture, and a setting cement was fabricated to test the mechanical properties and setting time, as well as the in vitro and in vivo behaviour of the actual PFD-CPC.

Without additives, brushite cements set almost instantly upon contact with water, so in order to generate comparable data of injectability and radiopacity of cements premixed with PFD, a non-setting cement formulation was prepared (Bohner et al., 2006). The non-setting cement was composed of $\beta$-tricalcium phosphate $(\beta$-TCP) and a liquid (either PFD or distilled water). The $\beta$-TCP powder was prepared by heating a stoichiometric mixture of calcium carbonate and dicalcium phosphate dihydrate at $900{ }^{\circ} \mathrm{C}$ for $14 \mathrm{~h}$ (Sigma-Aldrich) (Tamimi et al., 2009b). In order to assess the setting reaction of calcium phosphate cements premixed with PFD, a brushite cement powder was prepared from a homogeneous and equimolar mixture of monocalcium phosphate monohydrate (MCPM; ABCR, Karlsruhe, Germany) and $\beta$-TCP (1.00 g of MCPM for $1.23 \mathrm{~g}$ of $\beta$-TCP) (Tamimi et al., 2009b). The different cement powder formulations (setting and non-setting) were premixed with PFD in a range of powder-to-liquid ratios $(0.5-3.0 \mathrm{~g} / \mathrm{mL})$ to produce a stable cement paste (PFD-CPC) that set upon exposure to water (in case of the setting cements). Control cements were premixed with water instead of PFD. In order to stabilise the cement suspension in PFD, the cement powder was partially coated with magnesium stearate (MS) surfactant prior to mixing (Sigma-Aldrich). MS was dissolved in toluene (Fisher Scientific Company, Ottawa, ON, Canada) (1\% w/v), and the resulting solution was mixed with the CPC powder $(1: 1=\mathrm{w}: \mathrm{v})$. This process created a suspension that was left to dry at room temperature before the powders were flash heated to $80{ }^{\circ} \mathrm{C}$ until all toluene was eliminated. All in vitro and in vivo experiments using PFD-CPC were done with MS coated cement unless stated otherwise because the plain cement did not have sufficient injectability.

\section{Radiopacity of PFD loaded cements}

To evaluate the radiopacity of PFD containing bioceramics, $200 \mathrm{mg}$ of the non-setting cement powder was mixed with either water or PFD in different P:L ratios $(0.5-2.0 \mathrm{~g} / \mathrm{mL})$ and placed in a flat bottom glass test tube $(1.17 \mathrm{~cm} \varnothing)$. The radiopacity experiments were designed to show the effect 
of PFD on calcium phosphate radiopacity, for this reason we assessed the radiopacity in cement formulations ranging from no liquid phase at all $(\mathrm{P}: \mathrm{L}=1: 0[\infty])$ to a powder-toliquid ratio of 0.5 .

The samples were analysed with an X-ray densitometer (Lunar Piximius II, GE Medical Systems, Bedford, UK). Levels of radiopacity were given in units of Bone Mineral Density (BMD; $\mathrm{g} / \mathrm{cm}^{2}$ ) and radiographs were taken with an X-ray camera (Faxitron MX-20, Faxitron X-ray Corp, Wheeling, IL, USA) in triplicate. BMD values were compared with expected values for comparable amounts of bone mineral $(200 \mathrm{mg})$. Each formulation was prepared and tested in triplicate.

\section{Injectability of PFD loaded cements}

Two types of non-setting brushite cement powder were tested: pure $\beta$-TCP, or MS-coated $\beta$-TCP. The non-setting cement powder $(500 \mathrm{mg}$; with or without MS coating) was mixed with PFD or water at different P:L ratios (1.0$3.0 \mathrm{~g} / \mathrm{mL}$ ) and loaded in a $3 \mathrm{~mL}$ hypodermic syringe (BD, Franklin Lakes, NJ, USA). The syringes were adapted to fit a mechanical testing machine (Instron 5569; Instron, Canton, MA, USA), and an extrusion force was exercised at a constant velocity up to $15 \mathrm{~mm} / \mathrm{min}$. The experiments were stopped at a maximum force of $150 \mathrm{~N}$. The volume of extruded cement was measured and the cement injectability percentage was calculated by dividing the volume of extrude cement by the original volume of cement loaded in the syringe (Barralet et al., 2004). Triplicate measurements were performed for each specific sample condition. Injectability experiments were designed to test the effect of PFD on the most challenging conditions (high $\mathrm{P}: \mathrm{L}$ ratios). Therefore; we only show data on cements with high powder-to-liquid ratios (1.0-3.0). All cement formulations with low powder-to-liquid ratio $(\mathrm{P}: \mathrm{L}<1.0)$ had a comparable very high injectability $(>80 \%)$ in our experimental conditions.

\section{Setting reaction of $\mathrm{PFD}$ loaded cements}

Self-setting cement powder coated with MS was premixed with either PFD or water at a P:L of $3.0 \mathrm{~g} / \mathrm{mL}$. The cement paste was injected into moulds (12 $\mathrm{mm} \times 6 \mathrm{~mm} \mathrm{ø)}$ and placed under water at $37^{\circ} \mathrm{C}$. Setting time was measured with Gilmour needles, and the cements were tested for compressive strength and X-ray diffraction (XRD) after $24 \mathrm{~h}$ of incubation (Carey et al., 2005). Compressive strength of the cylindrical samples was measured with a universal testing machine (Instron ${ }^{\circledR} 5569$, Norwood, MA) at a crosshead speed of $0.1 \mathrm{~mm} / \mathrm{min}$. X-ray diffraction patterns of the ground cements were collected using a vertical-goniometer X-ray diffractometer (Philips model PW1710, Philips, Eindhoven, The Netherlands), equipped with a $\mathrm{Cu} \mathrm{K}$ radiation source. Data were collected from $5^{\circ}$ to $55^{\circ}$ with a step size of $0.02^{\circ}$ and a normalised count time of $1 \mathrm{~s}$ per step. Phase composition was examined by means of the International Centre for Diffraction Data (ICDD) reference patterns for $\beta$-TCP (PDF Ref. 09-0169), monetite (PDF Ref. 09-0080), hydroxyapatite (PDF Ref. 09-0432) and brushite (PDF Ref. 09-0077). The mechanism of the setting reaction of the cement system was investigated by Fourier Transform Infrared Spectroscopy (FTIR) (Spectrum System BX400-650; Perkin Elmer, Waltham, MA, USA) using a single bounce ZnSe diamond-coated ATR crystal. Spectra were recorded between 4000 and $350 \mathrm{~cm}^{-1}$ with a resolution of $4 \mathrm{~cm}^{-1}$, and 64 scans per run.

\section{In vitro evaluation of bone marrow cells growth in the} presence of PFD

In order to assess the potential benefits of PFD as an $\mathrm{O}_{2}$ delivery agent into bone regeneration sites we designed a series of experiments in which we evaluated BM cell survival in hypoxic conditions when PFD is added. According to our hypothesis, we expected to observe increased cellular survival rates when PFD was added to hypoxic cell culture. All studies involving animals or animal tissues were performed in accordance with the McGill University guidelines established by the Canadian Council on Animal Care. The effect of $\mathrm{N}_{2}$-PFD (deoxygenated), $\mathrm{O}_{2}$-PFD and PFD-CPC (oxygenated), on $\mathrm{BM}$ cell proliferation and differentiation was evaluated in cell cultures derived from mouse BM. Mice (C57BL6/J, male, 6 weeks old) were purchased from Charles River (Charles River Co., Wilmington, MA, USA) and BM cells were collected from mouse tibia and femora as described previously in the literature (Armstrong et al., 2009). Briefly, femora and tibia were dissected under sterile conditions and the surrounding muscles were detached from the bones. Tibia and femora were cut in half and the bone marrow was flushed with minimum essential medium (MEM), containing $10 \%$ serum and $1 \%$ antibiotics dispensed by a $10 \mathrm{~mL}$ syringe with a 26 -gauge needle. $\mathrm{BM}$ was flushed from the tibia and femora under aseptic conditions. Mouse-derived BM cells were then cultured in $75 \mathrm{~cm}^{2}$ tissue culture flasks $\left(2.5 \times 10^{6}\right.$ cells $\left./ \mathrm{cm}^{2}\right)$ in MEM

Table 1. Test conditions for in vitro incubation of mouse bone marrow stromal cells.

\begin{tabular}{|c|c|c|c|c|c|}
\hline Label & Whole medium & n cells & $\mathrm{N}_{2}$-PFD & $\mathrm{O}_{2}$-PFD & Well sealed \\
\hline US-WM & $2.0 \mathrm{~mL}$ & $\mathrm{n} / \mathrm{a}$ & $\mathrm{n} / \mathrm{a}$ & $\mathrm{n} / \mathrm{a}$ & No \\
\hline US-cells & “" & $1.5 \cdot 10^{5}$ & $\mathrm{n} / \mathrm{a}$ & $\mathrm{n} / \mathrm{a}$ & “" \\
\hline US-cells-PFD-N & “" & “" & $400 \mu \mathrm{L}$ & $\mathrm{n} / \mathrm{a}$ & “" \\
\hline US-cells-PFD-O & “" & “6 & $\mathrm{n} / \mathrm{a}$ & $400 \mu \mathrm{L}$ & “" \\
\hline S-WM & “" & $\mathrm{n} / \mathrm{a}$ & $\mathrm{n} / \mathrm{a}$ & $\mathrm{n} / \mathrm{a}$ & Yes \\
\hline S-cells & “" & $1.5 \cdot 10^{5}$ & $\mathrm{n} / \mathrm{a}$ & $\mathrm{n} / \mathrm{a}$ & “" \\
\hline S-cells-PFD-N & “" & “" & $400 \mu \mathrm{L}$ & $\mathrm{n} / \mathrm{a}$ & “" \\
\hline S-cells-PFD-O & “" & “" & $\mathrm{n} / \mathrm{a}$ & $400 \mu \mathrm{L}$ & “" \\
\hline
\end{tabular}

n/a: not applicable. S: sealed wells; US: unsealed wells; WM: whole medium without cells. 
with $10 \%$ foetal bovine serum, $1 \%$ antibiotics, $1 \%$ sodium pyruvate and $50 \mu \mathrm{g} / \mathrm{mL}$ of ascorbic acid (Sigma-Aldrich Canada, Oakville, ON, Canada). After 5 to 7 days, cells were detached with trypsin/EDTA and plated at a density of $5 \times 10^{3}$ cells $/ \mathrm{cm}^{2}$ in 48 well plates, onto the cell culture plastic for further experiments (Table 1).

In order to evaluate the effect of $\mathrm{O}_{2}$ release from PFD on BM cells survival, an experiment was designed in which cell culture wells were filled with each one of the conditions described in Table 1. The different PFD liquids added were mixed thoroughly with the medium. The exposure of the cell culture medium to atmospheric $\mathrm{O}_{2}$ was controlled by either keeping them unsealed (open to gas exchange with the surrounding atmosphere), or sealed from the incubator atmosphere. The wells were sealed with cover slips and paraffin, and only opened for final analysis. After predetermined time points $(0,1,3,7,14$ and 21 days), the culture wells were opened for immediate $\mathrm{O}_{2}$ measurement with an oxygen electrode (MI-730; Microelectrodes Inc., Bedford, NH, USA), MTT and fluorometric DNA assays for cell counting. Each sample time point and assay was performed in triplicate on an independent set of samples. No repeated measurements were done, in order to reduce the risk of oxygen contamination from the atmosphere of the samples upon analysis.

In order to assess activity of cellular enzymes with the MTT assay, culture medium was removed from the samples and $1 \mathrm{~mL}$ of $0.25 \mathrm{mg} / \mathrm{mL}$ MTT (Thiazolyl Blue Tetrazolium Bromide, Sigma M5655, Sigma-Aldrich) (prepared with cell culture medium) was added to each well (Carmichael et al., 1987). After $2.5 \mathrm{~h}$ of incubation at $37^{\circ} \mathrm{C}$, all MTT solution was removed and $1 \mathrm{~mL}$ DMSO was added to dissolve the formazan crystals. After $10 \mathrm{~min}$ of shaking, $200 \mu \mathrm{L}$ of DMSO solution from each well was added to 96-well plates to measure absorbance at $562 \mathrm{~nm}$ (EL800 Universal microplate reader, Bio-Tek Instruments, Winooski, VT, USA) (Carmichael et al., 1987). The absorbance per cell was obtained by dividing the absorbance by cell number resulting from Hoechst 33258 fluorometric DNA assay (see below), giving a normalised indicator of metabolic activity.

In order to perform the Hoechst 33258 fluorometric DNA assay, cell medium was removed by overturning plates onto paper towels and stored at $-80^{\circ} \mathrm{C}$. After thawing, $400 \mu \mathrm{L}$ of distilled water was added and incubated at $37^{\circ} \mathrm{C}$ for $1 \mathrm{~h} .400 \mu \mathrm{L}$ of $40 \mu \mathrm{g} / \mathrm{mL}$ Hoechst 33258 (Invitrogen/ Life Technologies, Paisley, UK; H3569) in TNE buffer (10 mM Tris, 1 mM EDTA, $2 \mathrm{M} \mathrm{NaCl}$, pH 7.4) was added to each well. Fluorescence was measured (excitation $346 \mathrm{~nm}$, emission $460 \mathrm{~nm}$ ) using SpectraMax M2 ${ }^{\mathrm{e}}$ Multimode Plate Reader (Molecular Devices, Sunnyvale, CA, USA). Cell number standard curve was obtained by the fluorescence measurement of the serial dilutions of cells in wells (Rago et al., 1990; Otto, 2005).

\section{In vitro injection of PFD-CPC}

All in vivo and in vitro assessment of the cements were performed on the MS-coated formulations in order to provide the adequate injectability. The biocompatibility of PFD-CPC was compared with that of CPC, by directly injecting $200 \mu \mathrm{L}$ of each cement mixture $(\mathrm{P}: \mathrm{L}=1.0)$ into separate cell culture wells previously seeded with bone marrow cells - as described earlier and with $2.0 \mathrm{~mL}$ of whole medium (we selected a cement formulation with a relative high PFD content, low P:L, in order to assess better the effect of PFD on the cells). Brushite cement is initially acidic, therefore in order to prevent immediate cell death during setting, the culture medium was refreshed whenever the $\mathrm{pH}$ dropped below 6.8, as many times as needed, in order to maintain $\mathrm{pH}$ neutrality. Afterwards, the cell cultures were incubated for different time points up to 21 days, and cells were counted at each time point (as described earlier).

The biocompatibility of the cements could only be assessed in normoxic conditions (unsealed containers). This was because cells incubated with self-setting cements (CPC and PFD-CPC) in hypoxic conditions (sealed containers) died completely within $1 \mathrm{~h}$, due to the rapid decrease in $\mathrm{pH}$ caused by the setting reaction of the cements when the medium is not refreshing (data not shown).

\section{In vivo injection of PFD-CPC}

In order to evaluate the in vivo behaviour of the new cement system, approximately $0.5 \mathrm{~mL}$ of premixed PFD-CPC (P:L $=2.5)$ was subcutaneously injected in the interscapular area through a $16 \mathrm{G}$ needle in $3 \mathrm{Balb}-\mathrm{C}$ mice. The interscapular area is very mobile, and excess movement could result in early disintegration of the cement before complete setting. For this reason, we selected a cement formulation with high powder to liquid ratio (2.5) that is less flowable and therefore more likely to remain stable after injection. Five days after injection, the animals were sacrificed and the samples were retrieved and fixed in paraformaldehyde. The cement was dissected from the tissue which was dehydrated, paraffin embedded and sectioned for histological evaluation. The cement composition was assessed with FTIR and XRD.

\section{In vivo implantation of PFD loaded bioceramics}

In order to obtain an accurate evaluation of the in vivo performance of CPC loaded with PFD in vivo, we assessed its effect in bone defects treated with prefabricated CPC implants.

The geometry of the rabbit ulna bone was studied, and a computer-generated design of the rabbit distal ulna diaphysis was prepared (Fig. 1A). Tubular brushite ceramic blocks were 3D-printed as per the computer design (Fig. 1B-C), following a previously reported technique for cement printing (Gbureck et al., 2007a).

A total of 8 New Zealand rabbits (12 weeks old) were anaesthetised and incisions were made in the forearms to expose the ulna bone. A $1 \mathrm{~cm}$ long bone defect was created in each ulna after removing the periosteum from the site (Fig. 1D-G). In four rabbits, the defects were filled with the 3D-printed implants without any additive (negative controls; $n=8$ ). In the other 4 rabbits, the marrow of the removed bone segment was collected, and prior to implantation, the inner chambers of the 3D-printed ceramics were loaded with $100 \mu \mathrm{L}$ of BM retrieved from the surgical sites. BM is an autologous source of mesenchymal stem cells that is commonly used for improving bone healing outcomes (Connolly, 1995). Moreover, previous studies 

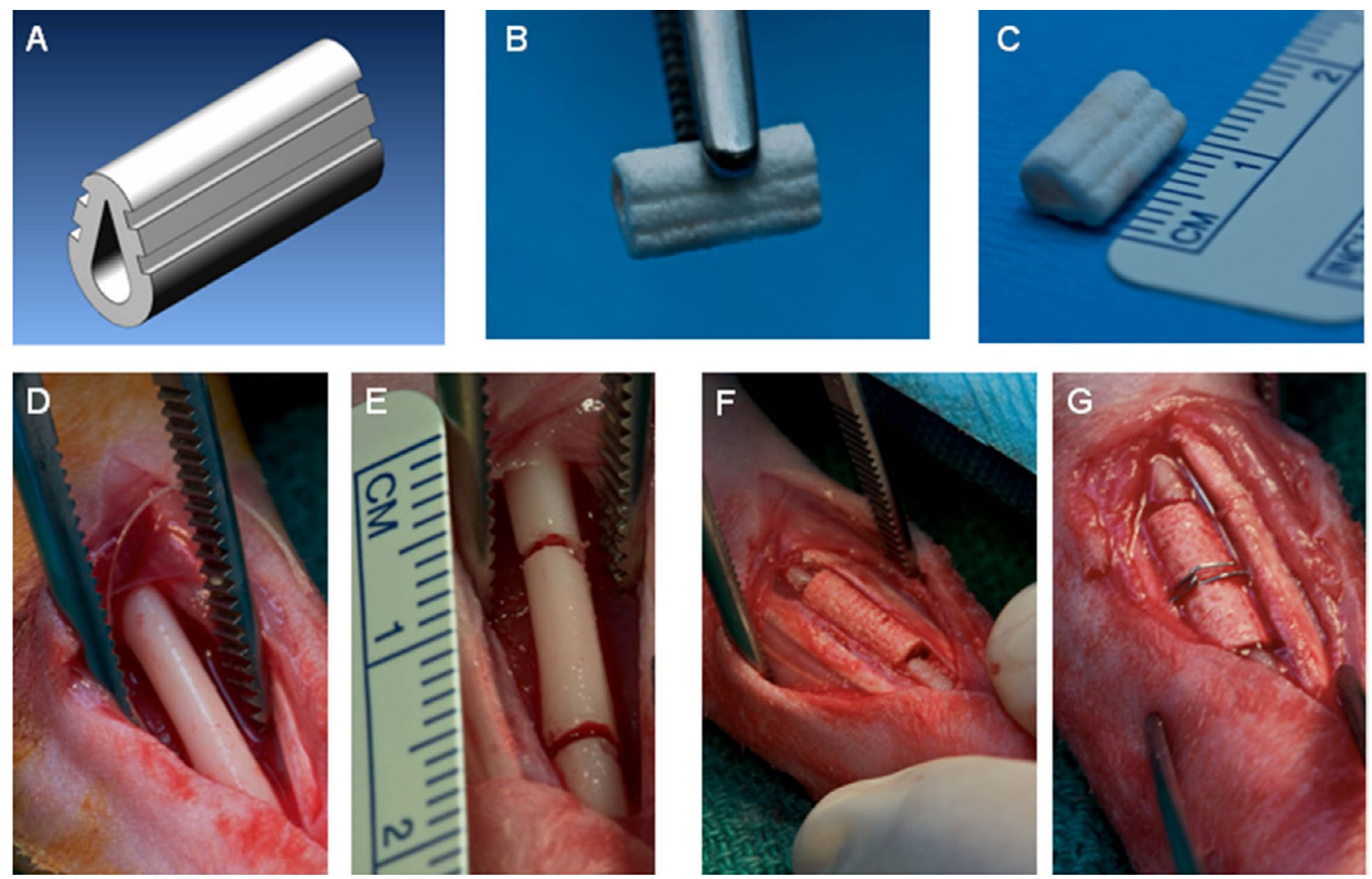

Fig. 1. (A) Computer generated design for a 3D printed bioceramic implant. (B,C) Brushite bioceramic printed as in the design in A. (D-G) surgical implantation of the 3D printed bioceramic in an ulna defect.

have demonstrated the presence of abundant numbers of MSCs in the BM of young rabbits, such as the ones used in this study (Huibregtse et al., 2003). Upon implantation into the ulna defects, $100 \mu \mathrm{L}$ of $\mathrm{O}_{2}$-PFD were added to the chamber of one of the implants (the experimental site; $n=4$ ) whereas the contralateral implants were loaded with $100 \mu \mathrm{L}$ saline solution (positive controls; $n=4$ ).

The implants were secured in the defect using surgical wire, and the wound was closed through layered suturing. The animals were left to heal for 2 weeks prior to euthanasia. Retrieved explants were fixed in formalin for $24 \mathrm{~h}$, washed in PBS and dehydrated in ascending concentrations of ethanol before embedding in polymethylmethacrylate resin (Heraeus Kulzer, Wehrheim, Germany). Longitudinal sections were cut using a Leica 1600 microtome saw (Leica, Bensheim, Germany) and stained with basic fuchsin and methylene blue for histological evaluation and histomorphometrical analysis.

Histomorphometrical measurements were performed on digital optical micrographs of the sections using the software ImageJ (NIH, Bethesda, MD, USA). Due to the difficulties in quantifying the exact area of the implants in contact with bone (since values are sensitive to the imaging technique and the magnification at which they are taken), we measured the outer perimeter of the implant covered by bone (not necessarily in direct contact), and total external perimeter. These values were used to calculate the percentage of the outer perimeter that were covered by bone. The relative area of soft tissue present inside the implant hollow cavity was obtained by measuring the area of soft tissue inside the implant and dividing it by the total area.

\section{Statistical analysis}

All data are presented as mean values \pm standard deviation. Statistical analysis was performed using SPSS software (SPSS for Windows version 12.0, SPSS Inc., Chicago, IL, USA). Data sets were assessed for normality using the Kolmogorov-Smirnov test. Sets passing the normality test were assessed using parametric techniques (One-Way ANOVA and Tukey post-hoc tests); non-normal sets were assessed using nonparametric techniques (Kruskal-Wallis One-Way Analysis of Variance on Ranks). Significance was set at a value of $p<0.05$.

\section{Results}

Injectability, radiopacity, cohesion and mechanical properties of cements with PFD

PFD did not appear to affect the visual appearance of the non-setting cements (Fig. 2A). All non-setting cements had some degree of radiopacity; however, X-ray radiographs revealed significant differences in radio-opacity between non-setting cements with PFD, and with water (Fig. 2B). The BMD of the non-setting cements premixed with PFD was significantly higher (20-30\%) than those prepared with distilled water only (Fig. 2C). Increasing the amount of PFD in the formulation increased the radiopacity in a dose dependant manner, whereas increasing the amount of water 

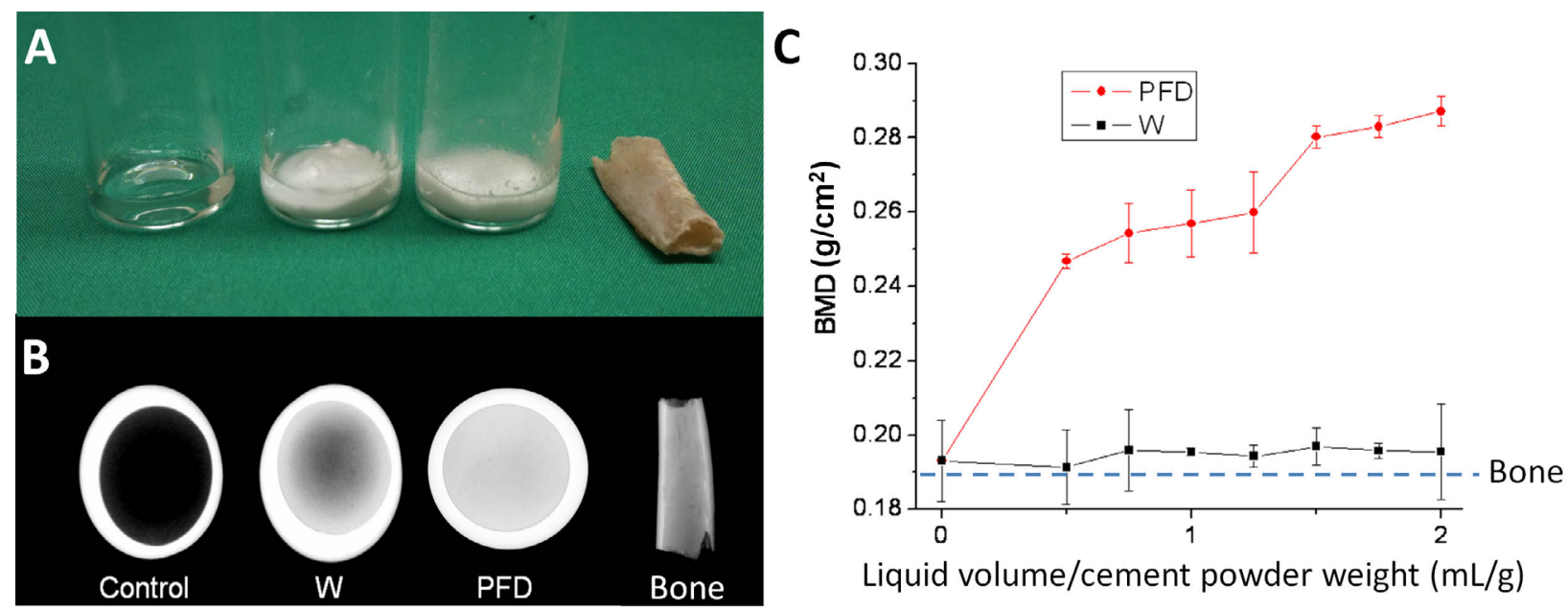

Fig. 2. (A,B) Photograph (B) and X-ray radiograph $(\mathbf{C})$ of 3 test tubes filled with: water (Control), non-setting cement mixed with water $(\mathrm{W})$, non-setting cement mixed with PFD (PFD) (P:L=1.0 g/mL), and a rabbit ulna section for comparison (Bone) (see Fig.1 D-E). (C) Effect of premixing with PFD on radiopacity of non-setting cement measured as BMD $\left(\mathrm{g} / \mathrm{cm}^{2}\right)$; the dashed line represents the BMD of a weight of bone comparable to the weight of the non-setting cement tested.
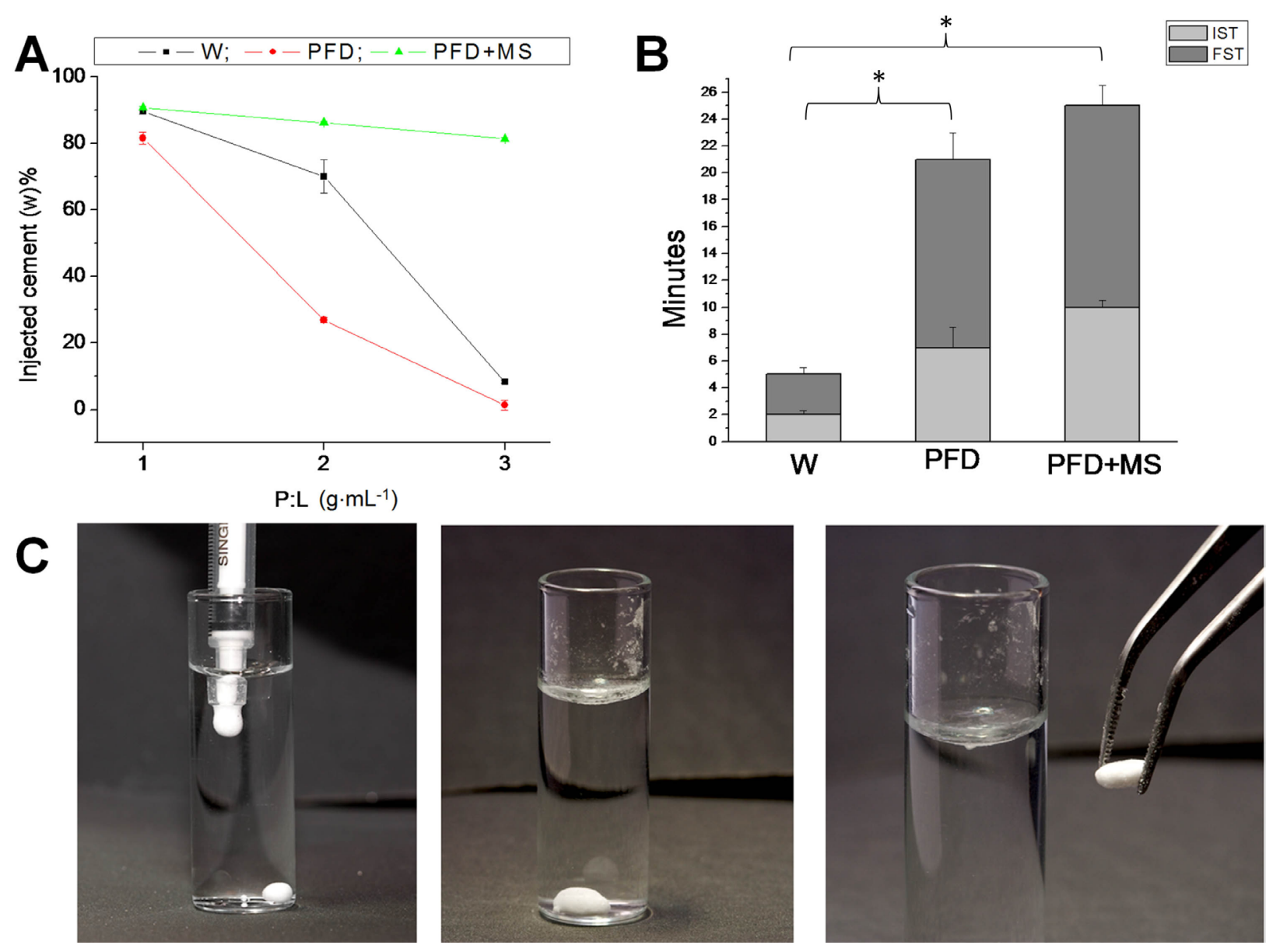

Fig. 3. (A) Graph depicting the injectability of non-setting cement premixed with water (W) or PFD (PFD), as well as the injectability of the non-setting cement coated with magnesium stearate (MS-coated) premixed with PFD. Injectability values are presented as a function of the powder-to-liquid ratio for each cement formulation. (B) Setting time, upon incubation in water, setting cement premixed with water (W) or PFD (PFD), as well as MS-coated setting cement premixed with PFD;* indicates significant differences between groups $(p<0.05)$. (C) Series of photographs of MS-coated setting cement premixed with PFD (P:L of $2.0 \mathrm{~g} / \mathrm{mL}$ ) showing (from left to right) injection into water, settling and final setting. 
had no effect on the radiopacity of the non-setting cement. The degree of radiopacity of the non-setting cement premixed with water was very similar to that of normal bone mineral, whereas cements premixed with PFD were significantly more radiopaque than bone. These results indicate that adding PFD to calcium phosphate cements can help distinguish them from bone in a radiograph.

The non-setting cement (pure $\beta$-TCP powder) mixed with water had poor injectability. Pure $\beta$-TCP could be premixed with PFD but the resulting formulation was only slightly injectable. However, the non-setting cement containing magnesium stearate was easily premixed with PFD resulting in a highly injectable formulation (Fig. 3A). The $\beta$-TCP powder coated with magnesium stearate could not be mixed with water due to its high hydrophobicity. Therefore, no cement could be prepared with this formulation. The P:L ratio of the different non-setting cements was inversely proportional to their injectability. However, the non-setting cements containing MS and PFD maintained a high degree of injectability even at high P:L ratios.

The setting cement powder set within 2 min after mixing with water. Setting cements premixed with PFD only set after injecting them into water, which occurred within a clinically relevant period of time $(\sim 10 \mathrm{~min})$, confirming that dissolution of PFD allowed the reaction of the cement with surrounding water, triggering the setting reaction (Fig. 3B, C). Once injected into water, the hydrophobicity of the PFD-premixed cement system prevented particle segregation, resulting in a high degree of cement cohesion (Fig. 3C). Also, the presence of PFD in the cement limited the initial reduction in $\mathrm{pH}$ caused by brushite cement setting reaction (Fig. 4). The mean compressive strength of the PFD-premixed cement (coated with MS), after storage in water (cement-to-water ratio = 1:20) for $24 \mathrm{~h}$ at $37^{\circ} \mathrm{C}$, was $2.3 \pm 1.3 \mathrm{MPa}$.

\section{Biocompatibility of PFD-CPC in vitro and in vivo}

In order to further test the biocompatibility PFD-CPC with bone cells in vitro, the CPC and PFD-CPC and PFD were incubated with BM cells. The cultured cells were tested for both vitality and capacity to differentiate. In the unsealed conditions, all BM cells implanted next to a water-mixed brushite CPC died within one day, while the cells incubated with PFD-CPC survived and proliferated for periods over 20 days - giving results similar to cement free controls (Fig. 5). Optical micrographs revealed that cell culture media incubated with CPC contained a large amount of loose particles, which were released from the setting cement (not shown), when compared to the culture medium of samples with PFD-CPC. This seemed to indicate an increase in cement cohesion as a result of adding PFD in the system, which was in agreement with injectability experiments.

The PFD-CPC setting reaction was evaluated in vivo by injecting the cement preparation subcutaneously in a murine model. Upon ex vivo examination, the cement was observed to have set to form brushite, PFD had been eliminated, and histological analysis revealed no signs of inflammatory response (Fig. 6).

The effect of PFD on BMSC survival in hypoxic culture The effect of PFD on $\mathrm{O}_{2}$ partial pressure in cell culture

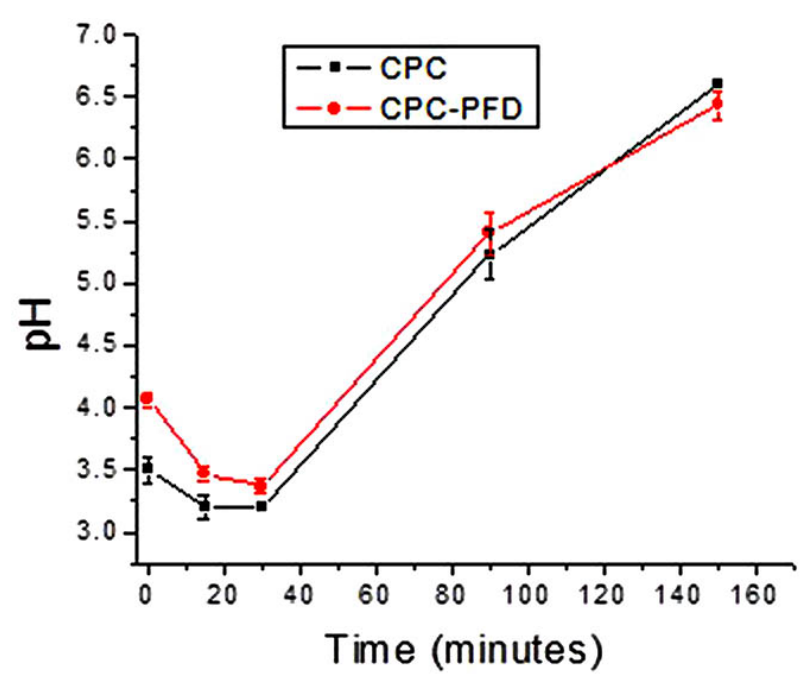

Fig. 4. Evolution of the $\mathrm{pH}$ of the cement incubation medium as a function of time. The graph shows the results of the regular brushite cement (CPC), and brushite cement mixed with PFD (CPC-PFD).

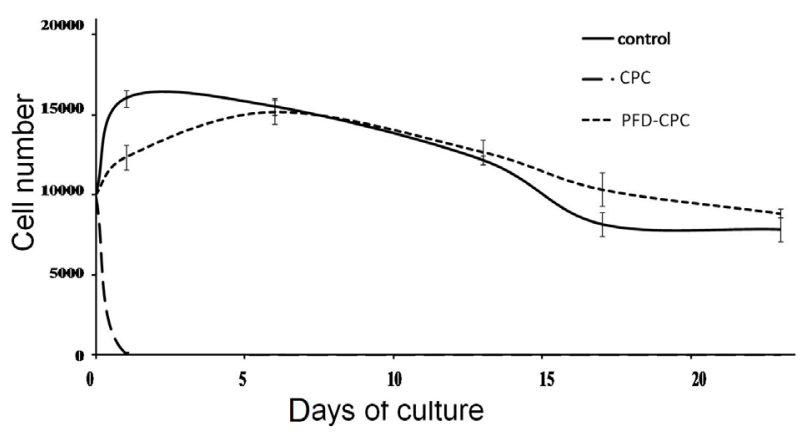

Fig. 5. Graph showing bone marrow cell survival over time in unsealed culture medium (control), unsealed culture medium with brushite cement (CPC) or unsealed culture medium with PFD-loaded cement (PFD-CPC).

media is shown in Fig. 7A. As might be anticipated, the concentration of oxygen in cell culture media was stable in the absence of cells, regardless of whether the containers were sealed (S-WM) or unsealed (US-WM). However, in the presence of cells, the concentration of $\mathrm{O}_{2}$ decreased over time, and this was more pronounced under sealed conditions.

Both $\mathrm{N}_{2}$-loaded PFD and $\mathrm{O}_{2}$-loaded PFD had a similar effect on $\mathrm{O}_{2}$ levels in sealed cell culture media. Adding $\mathrm{N}_{2}$-loaded PFD to the sealed cell culture medium had little effect on the $\mathrm{O}_{2}$ concentration (S-cells-PFD-N ${ }_{2}$ ), compared to the sealed containers without PFD (S-cells) (Fig. 7A). $\mathrm{O}_{2}$-loaded PFD increased the $\mathrm{O}_{2}$ concentration at day 3 (S-cells-PFD-O,$p<0.05$ ) compared to the other cell culture samples. However, $\mathrm{O}_{2}$ levels then rapidly dropped and by day 7 they were not significantly different from those measured in samples without PFD (S-cells) (Fig. 7A).

Cell survival was influenced by the availability of oxygen in the medium (Fig. 7B). For example, cells in unsealed samples (US-cells) survived longer than those in sealed wells (S-cells). Even though the presence of PFD caused an initial sharp decrease in cell numbers during 

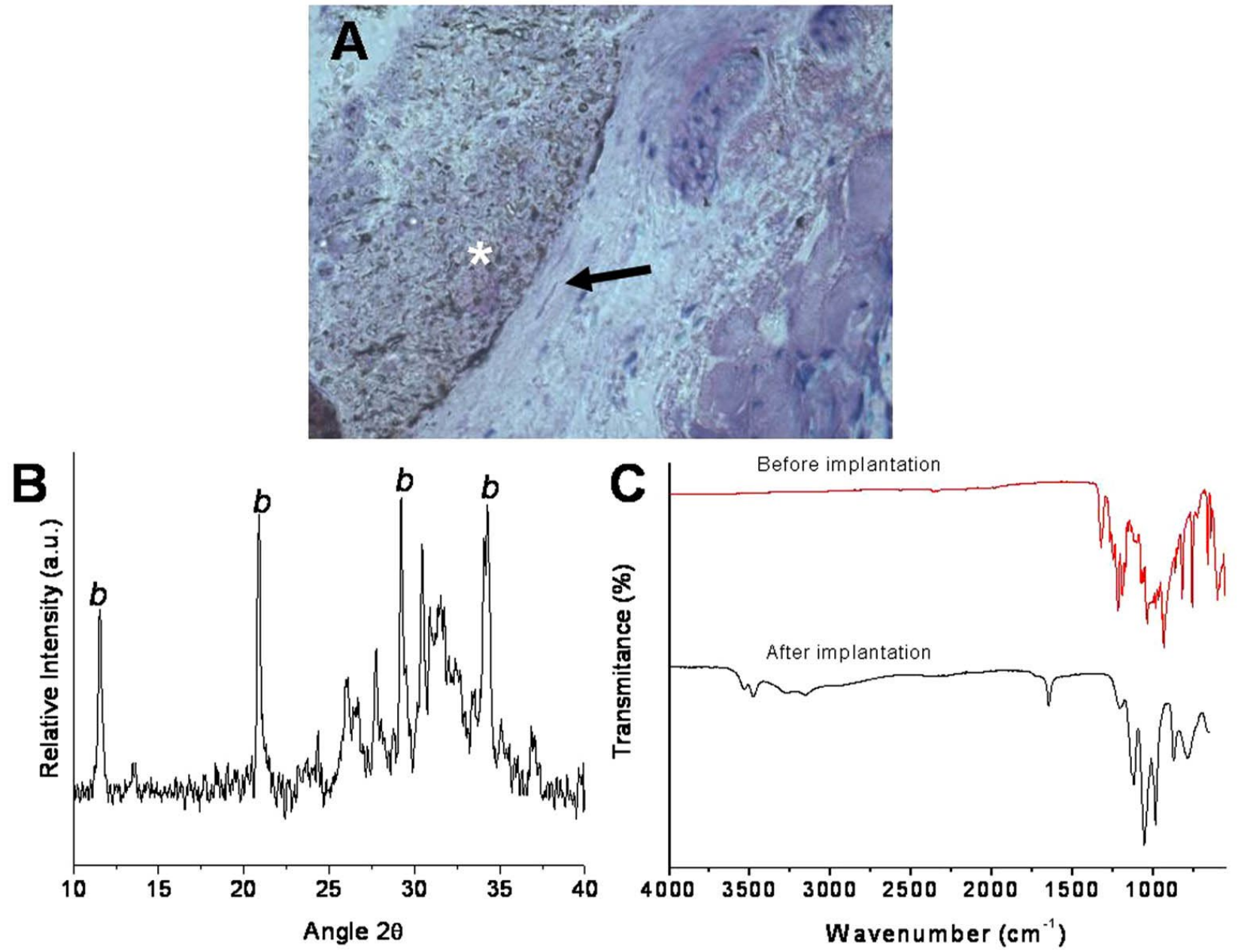

Fig. 6. (A) Histological micrograph of cement injected subcutaneously in mice showing the set cement $(*)$, and the connective tissue surrounding the implant (arrow). (B) X-ray diffraction pattern of the implanted cement, brushite intensity peaks (b) reveal that the material had reacted after implantation. (C) FTIR spectra of the cement prior and after implantation confirm that the cement has reacted after implantation showing that it is fully reacted to brushite. Monocalcium phosphate peaks characteristic of the unset brushite cement were detected in the cement formulation before implantation. $\mathrm{PO}_{2}$ peaks at 1158,1120 and 1092 as well as $\mathrm{P}(\mathrm{OH})_{2}$, peaks at 975, 962,914 and 888 indicated the presence of unreacted monocalcium phosphate while the strong bands at 1180-1310 are associated to the presence of PFD. Peaks associated with brushite were observed in the cement after implantation. OH peaks associated with DCPD formation appeared as expected at 3550, 3465, 3255, 3160 and $1640 \mathrm{~cm}^{-1}$ on top of the broad "free" water bands. Additional sharp PO peaks developed at 1110, 1050, 980 and $860 \mathrm{~cm}^{-1}$, consistent with dicalcium phosphate. No PFD related bands were detected after implantation, indicating that the organic solvent has been eliminated from the site.

the first days, cells in sealed wells survived longer when PFD was added. Throughout the experiment, a comparable number of cells were counted in both the $\mathrm{N}_{2}$-PFD and the $\mathrm{O}_{2}$-PFD cell culture samples.

Metabolic activity of the different cell culture conditions as a function of time was assessed using the MTT assay (Fig. 7C). Cells cultured with PFD, both $\mathrm{O}_{2}$ and $\mathrm{N}_{2}$ loaded, showed much lower metabolic activity than those without PFD during the first 3 days $(p<0.05)$. However, after day 7 metabolic activity in cells cultured with PFD increased dramatically, and was higher than in the cells without PFD (S-cells) $(p<0.05)$. US-cells presented a higher overall metabolic activity throughout the experiment.

In order to assess more accurately the metabolic activity, MTT values were normalised for cell number (Fig. 7D). In all conditions the cellular metabolic activity appeared to increase as a function of time, probably due to the decrease in cell numbers over time. However, during the first 3 days, cells cultured in PFD, both $\mathrm{O}_{2}$ and $\mathrm{N}_{2}$ loaded, had lower normalised metabolic activity than those cultured without PFD. After day 7, the normalised metabolic activity of cells cultured in PFD and normalised metabolic activities became insignificantly different between all the hypoxic (sealed) cultures through the remaining time points of the experiment.

Following implant explantation, qualitative surgical examination revealed that all the implants loaded with bone marrow (both PFD-loaded and saline-loaded) were firmly integrated with hard tissue growing on their external surface, whereas the control implants without BM appeared to be poorly integrated with the surrounding bone and covered with fibrous tissue. However, no quantitative 
A

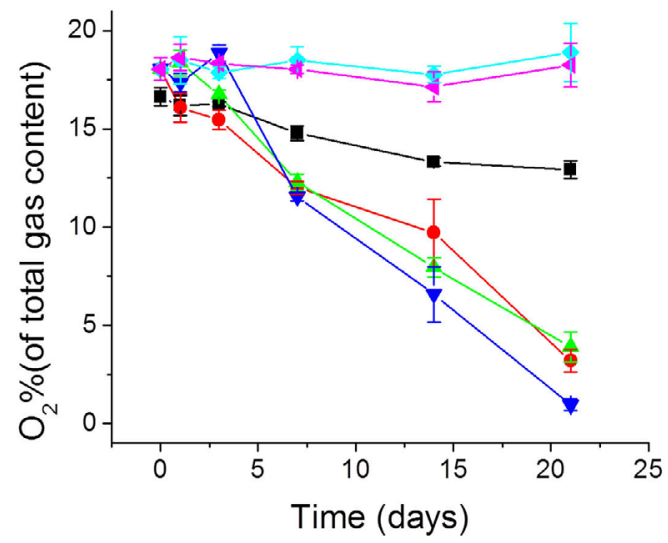

C

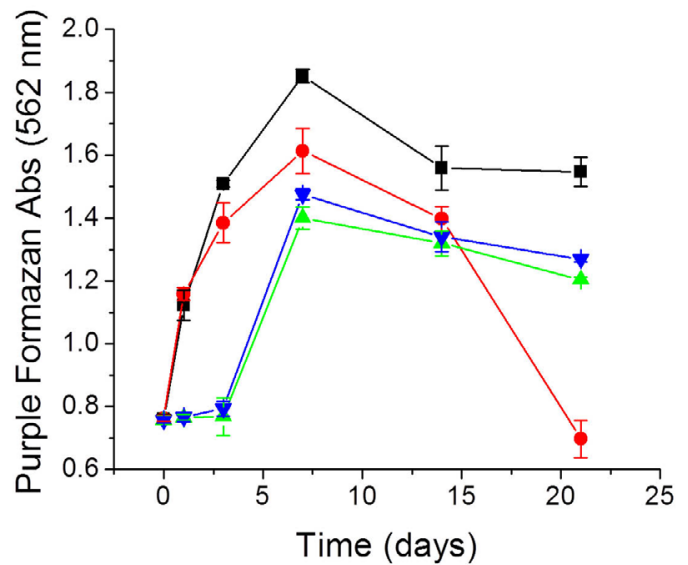

B
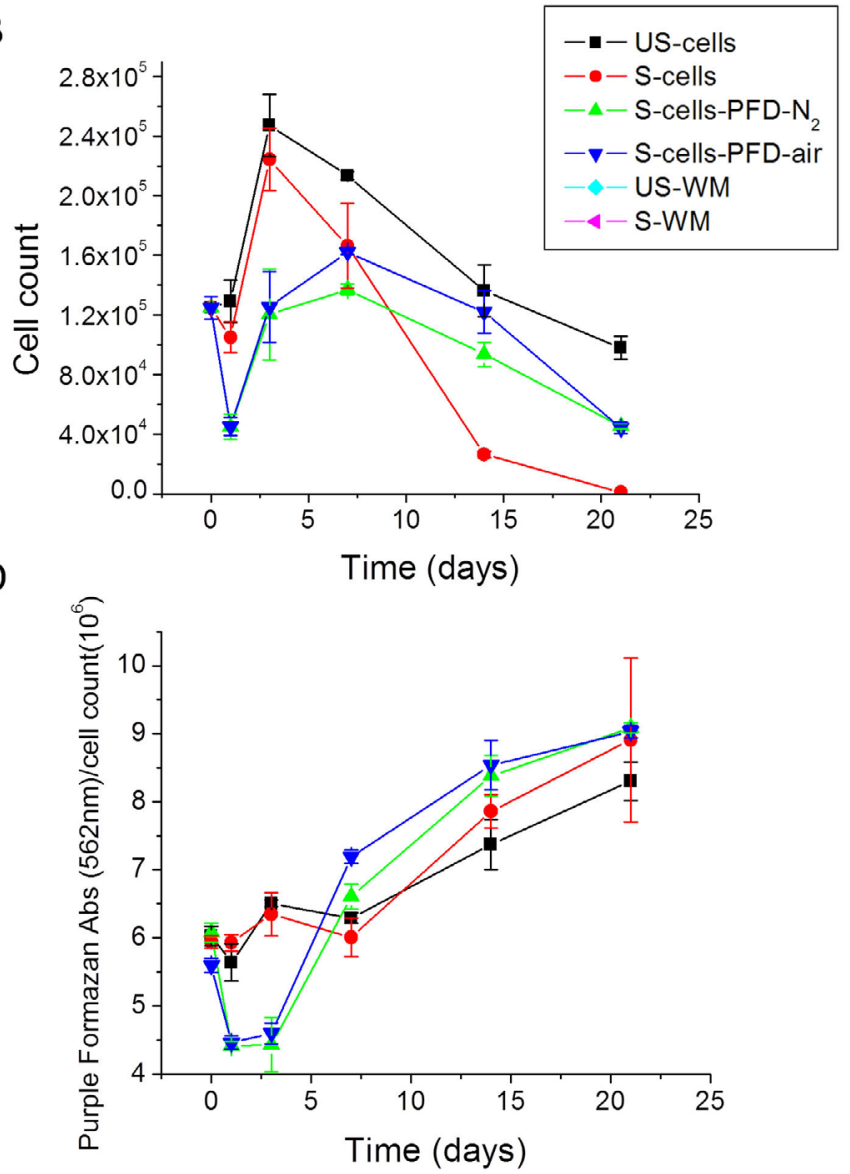

Fig. 7. (A) Atmospheric partial pressure of $\mathrm{O}_{2}$ in different cell culture media as a function of time. (B) Cell count as a function of time in different cell culture media. (C) Metabolic activity as a function of time. (D) Metabolic activity per cell number as a function of time. Figure labels are defined in Table 1.

analysis was performed to assess these macroscopic differences between the explants. Histological examination confirmed that bone tissue had formed only on the external surface of the $3 \mathrm{D}$-printed ceramics, while the marrow cavity of the ceramics had only soft tissue growing inside (Fig. 8A-F, Fig. 9). Interestingly, BS-SEM images revealed that the outer perimeter of the implants loaded with PFD were more irregular than the ones loaded not loaded with PFD, and often presented a gap between the new bone and the implant (Fig. 9).

Histomorphometric analysis of the $3 \mathrm{D}$ printed bioceramics revealed that soft tissue growth in the marrow of the implant was highest in implants loaded with BM and PFD $(p<0.05)$, followed by implants loaded with $\mathrm{BM}$ alone, and implants without BM (control) (Fig. 8). Similarly, bone growth on the external cortical surface of the implant was more extensive in the implants loaded with BM and PFD $(p<0.05)$, followed by implants loaded with $\mathrm{BM}$ alone, while implants with neither cells nor PFD had the least bone growth on their surface (Fig. 8).

\section{Discussion}

\section{Physico-chemical properties of premixed CPC}

Calcium phosphate cements suffer from several practical drawbacks which limit their clinical application, firstly they need to be mixed in theatre and secondly, despite having the capacity to be injectable (Barralet et al., 2004), they are by themselves insufficiently radio-opaque for fluoroscopically guided procedures (Chen et al., 2010). Self-setting CPCs have recently been developed by substituting the cement liquid phase with biologically inert, viscous, non-aqueous liquids such as glycerol and polyethylene glycol to deliver the cement reactants through a nozzle (Carey et al., 2005; $\mathrm{Xu}$ et al., 2007). The absence of water in these formulations enables the pre-mixed pastes to be stored in a ready-to-use form, and upon injection in vivo, the diffusion of water into the paste enables setting. Similarly, in our study, the use of PFD enable the preparation of injectable self-setting cements comparable to those previously prepared with glycerol or poly (ethylene) glycol.

Most inorganic bone regeneration biomaterials are difficult to distinguish from the native bone and usually insoluble barium and strontium salts are added to improve radiopacity (Alkhraisat et al., 2008; Yu et al., 2009). However, these additives serve no biological function and remain in the patient after application, additionally they can alter the rheology and other physical properties of CPCs (Alkhraisat et al., 2008). PFD is known to be radiopaque, and its fluorine groups are easily detected by magnetic resonance imaging (McFarland et al., 1985). In this proof of concept study we demonstrated significant improvement in radiopacity when PFD is included in a CPC formulation. 

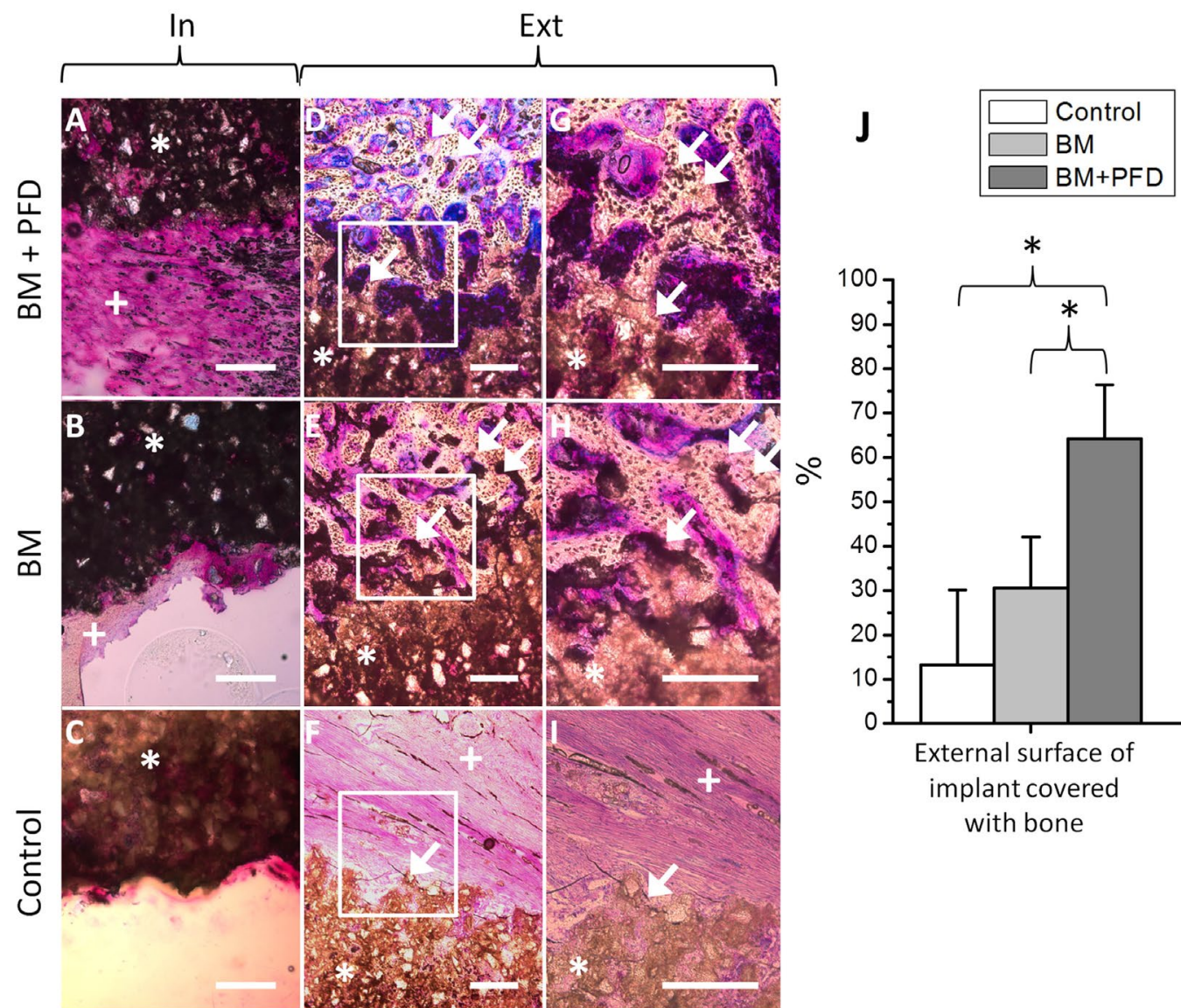

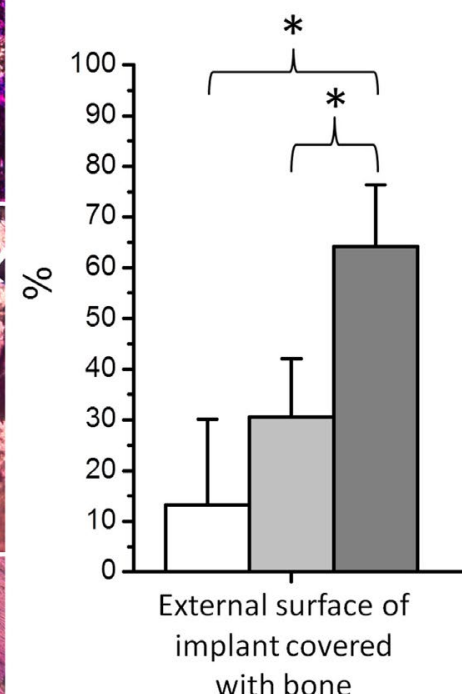

with bone

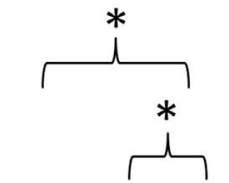

T

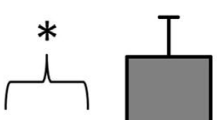

Internal volume of implant filled with soft tissue

Fig. 8. (A-I) Histological images showing implanted bioceramics alone (control), loaded with bone marrow (BM) from the same rabbit, and loaded with bone marrow combined with PFD (BM+PFD). (A-C) show the interface at the inner compartment of the cylinder (In) (original magnification x10; field of vision $=1.2 \mathrm{~mm}$ ). (D-F) show the interface at the external (Ext) surface of the cylindrical bioceramics (original magnification x10; field of vision = $1.2 \mathrm{~mm}$ ). (G-I) are higher magnification of the area indicated with a white square in D-F respectively (original magnification $\mathrm{x} 20$; field of vision $=0.6 \mathrm{~mm}$ ). The histological micrographs show the bioceramic (white star), the soft tissue growing inside the implant $(+)$, the bone growing on the outer surface of the implant (double arrow), and the bone implant-interface (single arrow). All sections were stained with basic fuchsin/methylene blue. The scale bar length $=200 \mu \mathrm{m}$. (J) Histomorphometric analysis of the histological sections showing the percentage of the external surface of the implant that is covered with bone, and the volume of the inner part of the implant that is filled with soft tissue; * indicates significant differences between groups $(p<0.05)$. The white column represents the control samples, the light grey represents the samples loaded bone marrow cells, and the dark grey the samples loaded with bone marrow cells combined with PFD.

It should also be remembered that halogenated decalins such as PFD can be partially brominated, increasing their radiopacity even further with little change in toxicity and physical properties (Long et al., 1971; Long et al., 1975; Lowe, 1991; Mattrey et al., 1987; McFarland et al., 1985).

\section{Oxygen delivery in vitro}

Oxygen levels in bone surgical sites have been previously measured in osteotomised rabbit tibiae, and were initially found to be as low as $1.3 \%$ (Kivisaari and Niinikoski, 1975; Aro et al., 1984). Therefore, early vascular regeneration is essential for the normal progress of fracture healing. Damaged blood vessels in a bone fracture require at least 2 weeks to re-establish the original blood flow in the healing area (Kurdy et al., 1996). It also takes at least 4 weeks for $\mathrm{O}_{2}$ levels to recover to normal physiological levels (Aro et al., 1984; Kivisaari and Niinikoski, 1975; Grayson et al., 2006; Grayson et al., 2007), although this response may vary depending on the specific charactersitics (size) of the bone fracture itself (Kurdy et al., 1996).

Hypoxia has a well-documented effect on bone formation and resorption (Kivisaari and Niinikoski, 1975; Aro et al., 1984; Kurdy et al., 1996; Grayson et al., 2006; Grayson et al., 2007). Under physiological conditions, oxygen partial pressure in the BM is estimated to range from $2 \%$ to $7 \%$. However, proliferation of MSCs is higher at atmospheric oxygen levels $(21 \%)$ than under physiological conditions (Grayson et al., 2006; Ma et al., 2009; Sengupta et al., 2010). A reduction in oxygen levels from $21 \%$ to $1 \%$ results in a reduction in cellular proliferation and adipogenic and osteogenic differentiation of human MSCs (Arnett et al., 2003; Knowles and 

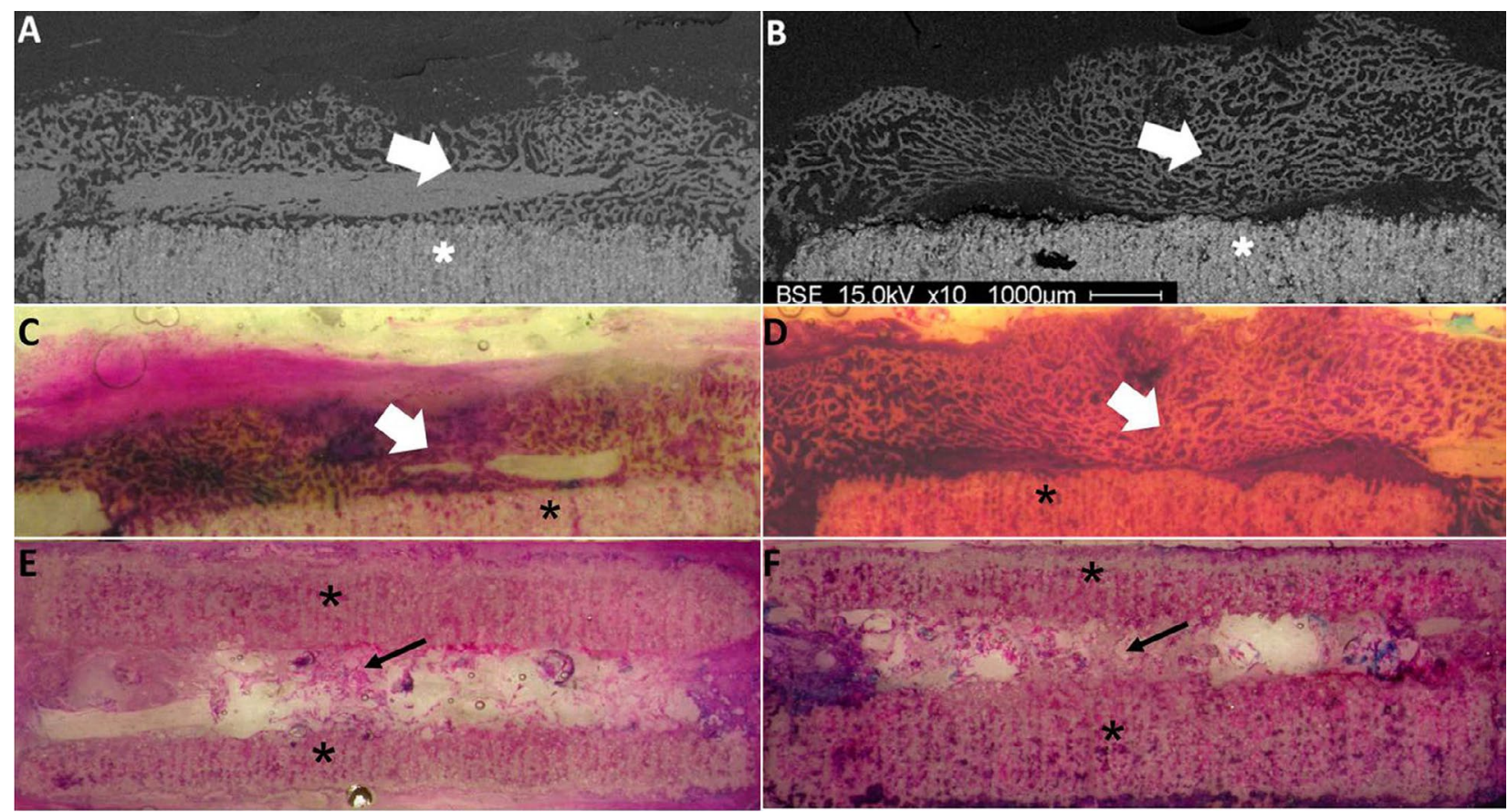

Fig. 9. BS-SEM images (A and $\mathbf{B}$ ) and light microscopy low magnification images (C and $\mathbf{D})$ of the outer surface of the implants, as well as light microscopy low magnification images of the inner hollow part of the implants (E and F). A, C and E show implants loaded with bone marrow, while B, D and F show the implants loaded with bone marrow and PFD. *: bioceramics; white arrow: bone callous; black arrow: marrow tissue.

Athanasou, 2009; Holzwarth et al., 2010). BM aspirate, which is rich in MSCs, is often used to aid bone healing (Jiang et al., 2002) and so the ability to manipulate localised oxygen concentrations around a graft substitute is highly relevant to healing optimisation.

In our in vitro experiments, unsealed cell free culture media maintained unaltered atmospheric levels of $\mathrm{O}_{2}$. Adding cells to the media resulted in a mild decrease in $\mathrm{O}_{2}$ partial pressure, reaching levels of $13 \%$ by day 21 , and a reduction in cell number over the same period, probably due to nutrient depletion since the culture medium was not replenished. On the other hand, $\mathrm{O}_{2}$ partial pressures were significantly lower in sealed cultures ( $4 \%$ by day 21$)$ and by day 21 all the cells had died. However, when incubated with PFD cell survival was significantly extended, although this effect was observed with both $\mathrm{O}_{2}$-PFD and $\mathrm{N}_{2}$-PFD. The quantity of PFD in a culture dish was $400 \mu \mathrm{L}$ PFD (added to $2 \mathrm{~mL}$ media). This could have a maximum oxygen content of $278 \mu \mathrm{M}$ in each well (of which PFD could have contributed $37 \%, 104 \mu \mathrm{M}$ ) (Lane, 1995). Oxygen consumption by cells is estimated as being $\sim 1 \mathrm{x}$ $10^{-7} \mu \mathrm{M} \cdot \mathrm{s}^{-1}$ per $10^{3}$ cells, as reported previously on dermal fibroblasts (Brown et al., 2007). Therefore over the duration of our experiment, assuming a constant cell number of 1.5 $\mathrm{x} 10^{5}$, the oxygen demand could be estimated in the order of $150 \times 10^{-7} \times 3600 \times 24 \times 21=27 \mu \mathrm{M} \mathrm{O}_{2}$, i.e, an order of magnitude less than what was available. Clearly then, both theoretical considerations and the experimental observation that $\mathrm{O}_{2}$-free PFD also prolonged cell viability (Fig. 7B) indicate that additional oxygen supply from PFD was not a factor in prolonging cell survival in hypoxic conditions. Therefore, PFD could have been affecting cell survival through another mechanism such as reducing metabolic activity. To test the hypothesis that PFD may reduce cell metabolic activity, we measured metabolic activity using the MTT assay. Our results showed that the presence of PFD did cause a reduction of the cellular metabolic rate during the first days of cell culture, but by day 7 the metabolic activity was similar for all culture conditions (Fig. 7D). This possible effect on metabolism could be also the reason behind the initial drop in cell numbers observed in bone marrow cells cultured in the presence of PFD. However, we are not sure why PFD appeared to decrease cell metabolic activity. A possible explanation could be the change in microenvironment from an aqueous osmotically balanced and nutritionally sufficient media to PFD. It may take some hours for proteins and other essential small molecules and ions to diffuse through the PFD layer on top of the cells. Clearly more work is required to elucidate the mechanism.

Carbon dioxide has a higher solubility in PFD than oxygen (Riess et al., 1988; Riess and Krafft, 1998; Soman and Banerjee, 2003; Tan et al., 2009), which is the basis for using PFD as artificial haemoglobin. Therefore, in sealed hypoxic conditions, it is likely that PFD was able to maintain gaseous homeostasis, which could have also caused the unexpectedly strong effect on cell survival, although future studies will have to be performed to clarify this possibility.

CPC samples without PFD had a dramatic negative effect on BMSC survival (no viable cells were detectable after day 3, Fig. 5). CPC without PFD had poor cohesion and released a large amount of particles when injected into the medium. In contrast, it seems that the excellent 
cohesion of PFD-CPC prevented the release of particles. Since the $\mathrm{pH}$ of the cell culture media was maintained at neutrality throughout both experimental conditions, it is possible that differences in cohesion could have caused the significant differences in cell survival between the waterbased CPC and the PFD-based CPC. Indeed particle release from biomaterials has been found to have a negative effect on cellular survival in the surrounding tissues (Lochner et al., 2011). However, the effect of particle release from cements on cellular survival needs further investigation.

\section{Tissue engineering with 3D printed bioceramics loaded with $\mathrm{BM}$ and $\mathrm{O}_{2}$ loaded $\mathrm{PFD}$}

3D-printed CPCs offer a unique opportunity to treat complicated bone defects by designing the implant according to the specific required geometry (Gbureck et al., 2007a). In previous studies we have shown the osteconductive and osteoinductive potential of 3D printed CPCs on goat vertebrae (Habibovic et al., 2008), and we have also been able to augment craniofacial bones using this 3D printed materials (Tamimi et al., 2009a). However, this is the first study in which we report the repair of a large defect in a long bone using a 3D printed bioceramic. Unfortunately, 3D-printed brushite implants alone had a limited capacity to resolve the large bone defect in a short period, probably due to the size of the defect. However, combining the 3D-printed CPC with BM and PFD resulted in a significant increase in bone formation around the implant within 2 weeks, and the implanted synthetic material was well integrated with the native bone.

Even though the number of mesenchymal stem cells in BM is limited, autologous BM has proven effectiveness for osteogenic stimulation in bone repair (Connolly et al., 1995). This could be the reason behind the increased soft and hard tissue formation around the implants loaded with BM compared to those without BM. Similarly to previous research, our study revealed that the combination of bioceramic implants with BM substantially increased the amount of bone growing on the outer implant surface (Kon et al., 2000; Marcacci et al., 2007). Interestingly, even though different amounts of bone grew on the outer surface of all the implants, no bone formation occurred within the inner compartment of any of the implants tested. In a very recent study, it was demonstrated that new bone formation in long bone defects originates solely from periosteal mesenchymal stem cells at the edges of the defect, and not from bone marrow cells (Grcevic et al., 2012). In our study, bone was creeping in from the outer edges of the defect, and on to the outer surface of the implants. The inner compartment of the cylindrical implants was partially isolated from the periosteum of the bone defects, and this could be the reason why we did not observe bone forming inside the cylindrical implants. In addition, due to the difference in accessibility to the tissues surrounding the implant, it is likely that the blood supply on the outer surface of the implant would be more abundant than in the inside. However, this issue will have to be investigated in future studies.

The porosity of the 3D-printed brushite bioceramics used in this study was $26 \%$, with an average pore size of $12.3 \mu \mathrm{m}$ (Gbureck et al., 2007b). This limited porosity is inadequate for cell migration through the walls of the bioceramics. However, it is enough to allow the movement of large molecules (Gbureck et al., 2007b). Therefore, the increase in bone formation on the outer surface of the implants loaded with BM may have been an indirect effect. MSCs secrete a broad range of bioactive molecules, such as growth factors, cytokines and chemokines (Caplan and Dennis, 2006; Meirelles et al., 2009). Accordingly, the higher amount of bone growth on the outer surface of the implants loaded with BM compared to the BM-free samples $(p<0.05)$, may have been caused by the trophic effect of the MSCs in the marrow tissue placed inside the implants. Although future studies will have to be performed in order to confirm this possibility.

Based on previous studies we would expect an oxygen content of $1.3 \%$ or lower (Aro et al., 1984) in the osteotomised ulna bone. This partial pressure of $\mathrm{O}_{2}$ is inadequate for osteogenesis, therefore the presence of PFD would be of interest in these specific conditions. Indeed, the bioceramics loaded with both $\mathrm{BM}$ and $\mathrm{O}_{2}$-PFD had more bone on the outer surface of the implant and more soft tissue in the inner part ceramic than the implants with BM alone. This result indicates that PFD might have benefited the survival of BM cells inside the implants, resulting in increased bone formation on the implant outer surface through the trophic effect of the bone marrow cells (Caplan and Dennis, 2006).

\section{Future studies}

In this study we have demonstrated that PFD increased the survival rate of BM cells under anaerobic condition, which translated to increased bone regeneration in vivo. These results show that combining stromal cells with PFD may be a viable approach for enhanced bone tissue engineering. However, future research will have to be done in order to fully understand how PFD prolongs cellular survival in hypoxic conditions.

Another possible application that has not been explored in this work is the potential use of PFD cement as a delivery system for signalling gases such as $\mathrm{NO}, \mathrm{CO}$ or $\mathrm{H}_{2} \mathrm{~S}$ into bone regeneration sites. These new type of materials may improve bone cell survival and differentiation in tissue engineering procedures.

BS-SEM observations revealed a gap between the mineralised tissues and the implants loaded with PFD. This gap could be due to two reasons: PFD could be having an inhibitory effect on mineralisation, or the implants are resorbing faster in the presence of PFD. In fact, BSSEM images revealed that the surface of implants loaded with PFD had more irregular surface outer surface than the PFD-free (an indication of higher resorption rate). However, our study was not designed to assess biomaterial resorption (due to the complex geometry of the implants) or osteoclast/macrophage activity (due to the absence of immune histochemistry markers), and future studies will have to be done in order to clarify whether or not PFD has any significant effect on biomaterial resorption in vivo and/ or mineralisation. 


\section{Conclusions}

In this study we have shown that anaerobic conditions have a negative effect on bone stromal cell survival. However, the presence of PFD into anaerobic culture media can prolong cell survival. The combination of PFD with a tissue engineering bioceramic increased the radiopacity, injectability and cohesion of bone cements. Additionally, the ability of bone-marrow-loaded bioceramics to regenerate bone is enhanced with the addition of PFD. We conclude that PFD might be a useful biomaterial in bone tissue engineering and warrants further investigation.

\section{References}

Alkhraisat MH, Moseke C, Blanco L, Barralet JE, Lopez-Carbacos E, Gbureck U (2008) Strontium modified biocements with zero order release kinetics. Biomaterials 29: 4691-4697.

Armstrong S, Pereverzev A, Dixon SJ, Sims SM (2009) Activation of P2X7 receptors causes isoformspecific translocation of protein kinase $\mathrm{C}$ in osteoclasts. J Cell Sci 122: 136-144.

Arnett TR, Gibbons DC, Utting JC, Orriss IR, Hoebertz A, Rosendaal M, Meghji S (2003) Hypoxia is a major stimulator of osteoclast formation and bone resorption. J Cell Physiol 196: 2-8.

Aro H, Eerola E, Aho AJ, Niinikoski J (1984) Tissue Oxygen-tesion in externally stabilized tibial fractures in rabbits during normal healing and infection. J Surg Res 37: 202-207.

Barralet JE, Grover LM, Gbureck U (2004) Ionic modification of calcium phosphate cement viscosity. Part II: hypodermic injection and strength improvement of brushite cement. Biomaterials 25: 2197-2203.

Bohner M, Doebelin N, Baroud G (2006) Theoretical and experimental approach to test the cohesion of calcium phosphate pastes. Eur Cells Mater 12: 26-35.

Brown MF, Gratton TP, Stuart JA (2007) Metabolic rate does not scale with body mass in cultured mammalian cells. Am J Physiol Regul Integr Comp Physiol 292: R2115-R2121.

Bueno EM, Glowacki J (2009) Cell-free and cell-based approaches for bone regeneration. Nat Rev Rheumatol 5: 685-697.

Caplan AI (1991) Mesenchymal stem-cells. J Orthop Res 9: 641-650.

Caplan AI, Dennis JE (2006) Mesenchymal stem cells as trophic mediators. J Cell Biochem 98: 1076-1084.

Carey LE, Xu HHK, Simon CG, Takagi S, Chow LC (2005) Premixed rapid-setting calcium phosphate composites for bone repair. Biomaterials 26: 5002-5014.

Carmichael J, Degraff WG, Gazdar AF, Minna JD, Mitchell JB (1987) Evaluation of a tetrazoliumbased semiautomated colorimetric assay-assessment of chemosensitivity testing. Cancer Res 47: 936-942.

Cheema U, Brown RA, Alp B, MacRobert AJ (2008) Spatially defined oxygen gradients and vascular endothelial growth factor expression in an engineered 3D cell model. Cell Mol Life Sci 65: 177-186.

Chen F, Liu C, Mao Y (2010) Bismuth-doped injectable calcium phosphate cement with improved radiopacity and potent antimicrobial activity for root canal filling. Acta Biomater 6: 3199-3207.

Connolly JF. Injectable bone marrow preparations to stimulate osteogenic repair (1995) Clin Orthop Relat Res 313: 8-18.

Gbureck U, Hozel T, Klammert U, Wurzler K, Muller FA, Barralet JE (2007a) Resorbable dicalcium phosphate bone substitutes prepared by 3D powder printing. Adv Funct Mater 17: 3940-3945.

Gbureck U, Vorndran E, Müller FA, Barralet JE. Low temperature direct $3 \mathrm{D}$ printed bioceramics and biocomposites as drug release matrices (2007b) J Control Release 122:173-80.

Goshima J, Goldberg VM, Caplan AI (1991) The osteoenic potential of cultured-expanded rat marrow mesenchymal cells assayed in vivo in calcium-phosphate ceramic blocks. Clin Orthop Relat Res 262: 298-311.

Grayson WL, Zhao F, Bunnell B, Ma T (2007) Hypoxia enhances proliferation and tissue formation of human mesenchymal stem cells. Biochem Biophys Res Commun 358: 948-953.

Grayson WL, Zhao F, Izadpanah R, Bunnell B, Ma T (2006) Effects of hypoxia on human mesenchymal stem cell expansion and plasticity in $3 \mathrm{D}$ constructs. J CellPhysiol 207: 331-339.

Grcevic D, Pejda S, Matthews BG, Repic D, Wang L, Li H, Kronenberg MS, Jiang X, Maye P, Adams DJ, Rowe DW, Aguila HL, Kalajzic I (2012) In vivo fate mapping identifies mesenchymal progenitor cells. Stem Cells 30: $187-96$.

Habibovic P, Gbureck U, Doillon CJ, Bassett DC, van Blitterswijk CA, Barralet JE (2008) Osteoconduction and osteoinduction of low-temperature 3D printed bioceramic implants. Biomaterials 29: 944-953.

Holzwarth C, Vaegler M, Gieseke F, Pfister SM, Handgretinger R, Kerst G, Mueller I (2010) Low physiologic oxygen tensions reduce proliferation and differentiation of human multipotent mesenchymal stromal cells. BMC Cell Biol 11:11.

Huibregtse BA, Johnstone B, Goldberg VM, Caplan AI (2000) Effect of age and sampling site on the chondro-osteogenic potential of rabbit marrow-derived mesenchymal progenitor cells. J Orthop Res. 18:18-24.

Jeng MJ, Yang SS, Wolfson MR, Shaffer TH (2003) Perfluorochemical (PFC) combinations for acute lung injury: an in vitro and in vivo study in juvenile rabbits. Pediatr Res. 53(1):81-88.

Jewitt N, Anthony P, Lowe KC, de Pomerai DI (1999) Oxygenated perfluorocarbon promotes nematode growth and stress-sensitivity in a two-phase liquid culture system. Enzyme Microb Technol 25: 349-356.

Jiang YH, Jahagirdar BN, Reinhardt RL, Schwartz RE, Keene CD, Ortiz-Gonzalez XR, Reyes M, Lenvik T, Lund T, Blackstad M, Du JB, Aldrich S, Lisberg A, Low WC, Largaespada DA, Verfaillie CM (2002) Pluripotency 
of mesenchymal stem cells derived from adult marrow. Nature 418: 41-49.

Kivisaari J, Niinikoski J (1975) Tissue oxygen and carbon-dioxide tensions in healing rabbit tibias. Acta Orthop Scand 46: 269-279.

Knowles HJ, Athanasou NA (2009) Acute hypoxia and osteoclast activity: a balance between enhanced resorption and increased apoptosis. J Pathol 218: 256-264.

Kon E, Muraglia A, Corsi A, Bianco P, Marcacci M, Martin I, Boyde A, Ruspantini I, Chistolini P, Rocca M, Giardino R, Cancedda R, Quarto R (2000) Autologous bone marrow stromal cells loaded onto porous hydroxyapatite ceramic accelerate bone repair in critical-size defects of sheep long bones. J Biomed Mater Res 49: 328-337.

Kruyt MC, Delawi D, Habibovic P, Oner FC, van Blitterswijk CA, Dhert WJA (2009) Relevance of bone graft viability in a goat transverse process model. J Orthop Res 27: 1055-1059.

Kurdy NMG, Weiss JB, Bate A (1996) Endothelial stimulating angiogenic factor in early fracture healing. Injury 27: 143-145.

Lane TA (1995) Perfluorochemical-based artificial oxygen-carrying red-cell substitutes. Transfus Sci 16: 1931.

Lochner K, Fritsche A, Jonitz A, Hansmann D, Mueller P, Mueller-Hilke B, Bader R (2011) The potential role of human osteoblasts for periprosthetic osteolysis following exposure to wear particles. Int J Mol Med; 28:1055-1063.

Long DM, Liu M, Alrenga P, Szanto PS (1971) Application of perfluorocarbon compounds as radiopaque agents. Surg Forum 22: 207-209.

Long DM, Liu MS, Szanto PS, Arambulo AS, Rosen AL (1975) Perfluorocarbon compounds as X-ray contrast media in the lungs. Bull Soc Int Chir 34: 137-141.

Lowe KC (1991) Perfluorochemicals - blood and beyond. Adv Mater 3: 87-93.

Ma T, Grayson WL, Froehlich M, Vunjak-Novakovic G (2009) Hypoxia and stem cell-based engineering of mesenchymal tissues. Biotechnol Prog 25: 32-42.

Marcacci M, Kon E, Moukhachev V, Lavroukov A, Kutepov S, Quarto R, Mastrogiacomo M, Cancedda $\mathrm{R}$ (2007) Stem cells associated with macroporous bioceramics for long bone repair: 6-to 7-year outcome of a pilot clinical study. Tissue Eng 13: 947-955.

Mattrey RF, Strich G, Shelton RE, Gosink BB, Leopold GR, Lee T, Forsythe J (1987) Perfluorochemicals as US contrast agents or tumor imaging and hepatosplenographypreliminary clinical results. Radiology 163: 339-343.

McFarland E, Koutcher JA, Rosen BR, Teicher B, Brady TJ (1985) In vivo F-19 NMR imaging. J Comput Assist Tomogr 9: 8-15.

Meijer GJ, de Bruijn JD, Koole R, van Blitterswijk CA (2008) Cell based bone tissue engineering in jaw defects. Biomaterials 29: 3053-3061.

Meirelles LdS, Fontes AM, Covas DT, Caplan AI (2009) Mechanisms involved in the therapeutic properties of mesenchymal stem cells. Cytokine Growth Fact Rev 20: 419-427.

Ohgushi H, Goldberg VM, Caplan AI (1989) Heterotopic osteogenesis in porous ceramics induced by marrow-cells. J Orthop Res 7: 568-578.
Otto WR (2005) Fluorimetric DNA assay of cell number. Methods Mol Biol 289: 251-262.

Pilarek M, Szewczyk KW (2008) Effects of perfluorinated oxygen carrier application in yeast, fungi and plant cell suspension cultures. Biochem Eng J 41: 38-42.

Pittenger MF, Mackay AM, Beck SC, Jaiswal RK, Douglas R, Mosca JD, Moorman MA, Simonetti DW, Craig S, Marshak DR (1999) Multilineage potential of adult human mesenchymal stem cells. Science 284: 143-147.

Putyatina TK, Aprosin UD, Afonin NI (1994) The elimination peculiarities of perfluorocarbon emulsions stabilized with egg yolk phospholipid. Artif Cells Blood Substit Immobil Biotechnol 22:1281-1285.

Rago R, Mitchen J, Wilding G (1990) DNA fluorometric assay in 96-well tissue-culture plates using Hoechst-33258 after cell-lysis by freezing in distilled water. Anal Biochem 191: 31-34.

Riess JG, Krafft MP (1998) Fluorinated materials for in vivo oxygen transport (blood substitutes), diagnosis and drug delivery. Biomaterials 19: 1529-1539.

Riess JG, Arlen C, Greiner J, Leblanc M, Manfredi A, Pace S, Varescon C, Zarif L (1988) Design, synthesis and evaluationof fluorocarbons and surfactants for in vivo application new polyhydroxylated surfactants. Biomater Artif Cell Artif Organs 16: 421-430.

Roser BJ, Garcia De Castro A, Maki J (1999) Composition anf method for stable injectable liquids. In: US patent 6'190'701, Cambridge Biostability Ltd., UK.

Sengupta S, Park S-H, Patel A, Carn J, Lee K, Kaplan DL (2010) Hypoxia and Amino Acid Supplementation Synergistically Promote the Osteogenesis of Human Mesenchymal Stem Cells on Silk Protein Scaffolds. Tissue Eng Part A 16: 3623-3634.

Soman N, Banerjee R (2003) Artificial vitreous replacements. Biomed Mater Eng 13: 59-74.

Song-Ling L, Maturu KP(1975). Permanent suspension pharmaceutical dosage form. In: US Patent 3'996'355, American Home Prod Corp, USA.

Tamimi F, Torres J, Gbureck U, Lopez-Cabarcos E, Bassett DC, Alkhraisat MH, Barralet JE (2009a) Craniofacial vertical bone augmentation: A comparison between $3 \mathrm{D}$ printed monolithic monetite blocks and autologous onlay grafts in the rabbit. Biomaterials 30: 6318-6326.

Tamimi F, Torres J, Lopez-Cabarcos E, Bassett DC, Habibovic P, Luceron E, Barralet JE (2009b) Minimally invasive maxillofacial vertical bone augmentation using brushite based cements. Biomaterials 30: 208-216.

Tan Q, El-Badry AM, Contaldo C, Steiner R, Hillinger S, Welti M, Hilbe M, Spahn DR, Jaussi R, Higuera G, van Blitterswijk CA, Luo Q, Weder W (2009) The effect of perfluorocarbon-based artificial oxygen carriers on tissueengineered trachea. Tissue Eng Part A 15: 2471-2480.

Xu HHK, Carey LE, Simon CG Jr, Takagi S, Chow LC (2007) Premixed calcium phosphate cements: Synthesis, physical properties, and cell cytotoxicity. Dent Mater 23: 433-441.

Yu T, Ye J, Wang Y (2009) Preparation and characterization of a novel strontium-containing calcium 
phosphate cement with the two-step hydration process. Acta Biomater 5: 2717-2727.

\section{Discussion with Reviewers}

Reviewer I: Do you think that oxygen is being released from the PFD? If so, why was there no difference from the nitrogen-infused and the oxygen-infused samples? If not, why not?

Authors: We designed our study to assess whether or not PFD may be acting as a reservoir of Oxygen that releases gases until equilibrium is reached with the surrounding environment. However, our data indicate that $\mathrm{O}_{2}$ seems to be released very fast and equilibrium is reached fairly quickly during the first hours. That is why differences in $\mathrm{O}_{2}$ release between the nitrogen-infused and oxygen-infused samples were negligible. 